\title{
Fora i blogi informatyczne w świetle wybranych zagadnień składni języka ukraińskiego. „Ja” a komunikacja internetowa
}

W swych najbardziej podstawowych założeniach Internet (początkowo, czyli od końca lat sześćdziesiątych po rok 1980, funkcjonujący pod nazwą ARPANET ${ }^{1}$ ) służyć miał zwiększeniu amerykańskiego potencjału naukowego. Cel ten miał zostać osiągnięty przez połączenie oddalonych od siebie jednostek badawczych dysponujących sprzętem komputerowym. Taki „zdalny” sposób wymiany myśli i poglądów zainicjowany ponad pół wieku temu, w diametralnie zmienionej już dzisiaj rzeczywistości, zarówno realnej, jak i wirtualnej, zdominował współczesny świat. Sam Internet natomiast stał się dla wielu narzędziem pracy, komunikacji, źródłem poznawania świata czy sposobem na spędzanie wolnego czasu.

Internet zrewolucjonizował dotychczasowe sposoby komunikacji międzyludzkiej, całkowicie wypierając np. zastosowanie telegrafu, znacznie ograniczając użycie faksów, gruntownie zmieniając tradycyjne podejście do prowadzenia korespondencji. Nie ulega wątpliwości, że komunikowanie się właśnie za pośrednictwem łączy internetowych jest dziś podstawową formą kontaktu pośredniego.

Zagadnieniom komunikacji w Internecie poświęcono liczne publikacje. Jednym $\mathrm{z}$ autorów zajmujących się tym problemem jest między innymi Stanisław Juszczyk $^{2}$, który zwrócił uwagę na wiele istotnych aspektów związanych z in-

${ }^{1}$ ARPANET (ang. Advanced Research Projects Agency Network) - pierwsza sieć komputerowa bazująca na rozproszonej architekturze oraz protokole internetowym TCP/IP, ,protoplasta" Internetu. Funkcjonuje do dziś jako sieć stricte wojskowa.

2 S. Juszczyk, Internet. Wspótczesne medium komunikacji społecznej, „Edukacja i Dialog” 2011, nr 5-6, s. 42-46. 
terakcjami społecznymi zachodzącymi w przestrzeni wirtualnej. Podkreślając pozytywy nowoczesnych sposobów porozumiewania się (prostotę, oszczędność czasu i finansów, ogólną dostępność, zacieśnianie więzów rodzinnych i kontaktów towarzyskich oraz ich kontynuację w świecie realnym, trójtorowość komunikowania się — model interpersonalny, grupowy i masowy, poznawanie świata, alternatywność względem oficjalnych kanałów informacji itd.), badacz skupił się na kwestiach relacji interpersonalnych, zaletach oraz zagrożeniach wynikających $\mathrm{z}$ funkcjonowania $\mathrm{w}$ sieci. Te $\mathrm{i}$ inne zagadnienia związane $\mathrm{z}$ problemem komunikacji językowej w Internecie ze wszystkimi jej aspektami stanowią także jeden z kierunków badawczych opracowywanych przez Jana Grzenię ${ }^{3}$, który wyróżnia jej trzy rodzaje: typ konwersacyjny (m.in. komunikatory, czaty), korespondencyjny (m.in. poczta elektroniczna, fora dyskusyjne) oraz hipertekstowy (teksty dostępne w sieci).

Porozumiewanie się z wykorzystaniem Internetu jest przez polskich oraz ukraińskich językoznawców i medioznawców tematem poruszanym stosunkowo często. Dość przytoczyć prace takich badaczy, jak: Wojciech Burszta ${ }^{4}$, Wiesław Godzic $^{5}$, Dorota Gut ${ }^{6}$, Joanna Jagodzińska ${ }^{7}$, Igor Miecik ${ }^{8}$, Marta Olcoń ${ }^{9}$, Myrosława Rudyk ${ }^{10}$, Luba Strelbićka ${ }^{11}$, Hałyna Zymoweć ${ }^{12}$ czy Natalija Iwanowa ${ }^{13}$. Dominują tu jednak opracowania o charakterze kulturologicznym, socjologicznym czy filozoficznym. Prac, w których zjawisko komunikacji internetowej rozpatrywane byłoby przez pryzmat składni języka ukraińskiego czy przy uwzględnieniu problematyki terminologicznej (w tym informatycznej) lub też kwestie wpływu języka angielskiego na ukraińszczyznę (zwłaszcza w obrębie tekstów o charakterze informatycznym) ostatniego ćwierćwiecza jest stosunkowo niewie-

3 J. Grzenia, Komunikacja językowa w Internecie, Warszawa 2007, s. 43.

${ }^{4}$ W.J. Burszta, Język hiperrzeczywistości - hiperrzeczywistość języka, [w:] „Kultura i przyszłość”. Przyszłość języka, red. S. Krzemień-Ojak, B. Nowowiejski, Białystok 2001, s. 133-145.

${ }^{5} \mathrm{~W}$. Godzic, Język w Internecie: Czy piszemy to, co myślimy? [w:] Język w mediach masowych, red. J. Bralczyk, K. Mosiołek-Kłosińska, Warszawa 2000, s. 176-185.

${ }^{6}$ D. Gut, Pisze więc jestem. O języku Internetu, „Konteksty”, nr 1-2, Warszawa 1999.

7 J. Jagodzińska, Dyskurs internetowy, [w:] Czynności tworzenia i rozumienia wypowiedzi, red. J. Porayski-Pomsta, „Studia Pragmalingwistyczne” 3, Warszawa 2002, s. 207-227.

${ }^{8}$ I.T. Miecik, Polska rozmowa internetowa, „Polityka”, nr 11, Warszawa 2005, s. 3-10.

${ }^{9}$ M. Olcoń, Blog jako dokument osobisty: Specyfika dziennika prowadzonego w Internecie, „Kultura i Społeczeństwo”, nr 2 (XLVII), Warszawa 2003, s. 123-143.

10 М. Рудик, Украӥнське слово в Інтернеті, http://www.franko.lviv.ua/faculty/jur/publications/zbirnyk07/Zbirnyk07_Rudyk.htm 2006 [dostęp: 8.05.2012].

11 Л. Стрельбіцька, Інтернет як полігон розвитку природної мови, „Вісник Нац. ун-ту »Львівська політехніка«. Проблеми української термінології”, № 538, Львів 2005, s. 33-38.

12 Г. Зимовець, Структурно-прагматичні характеристики жанру інтернет-сайту, „Лінгвістика XXI століття: нові дослідження і перспективи” № 3, Київ 2009, s. 108-115.

${ }^{13} \mathrm{H}$. Іванова, Мовна ситуація в украӥнському віртуальному просторі, http://novamova. org/blog/2009/01/ukr-lang-virt-space/ [dostęp: 20.04.2011]. 
le (m.in. Ałła Nikołajewa ${ }^{14}$, Lilija Filuk ${ }^{15}$, Ałła Lipinśka ${ }^{16}$, Inesa Bajbakowa ${ }^{17}$, Dmytro Szczerba ${ }^{18}$, Ihor Hryhorowycz ${ }^{19}$, Iryna Skorejko-Swirśka ${ }^{20}$, Mychajło Plesza $\mathrm{i}$ in. ${ }^{21}$ ).

Ze względu na dość szeroki zakres zagadnienia w niniejszym artykule (po części będącym kontynuacją tekstu pt. Особливості функціонування повідомлень у розділі „Високі технологї” на веб-форумі „Домівка.Net”22) skupiono się na dwóch w pewnym stopniu odległych, a co za tym idzie ciekawych z punktu widzenia występowania niektórych struktur składniowych, obszarach komunikacyjnych, które powstały i funkcjonują dzięki Internetowi - forach $^{23}$

${ }^{14}$ А. Ніколаєва, Лексико-семантичні особливості термінів програмування, баз даних, мереж та обробки інформації, „Вісник Харківського університету. Серія: Філологія”, № 473, Харків 2000, s. 140-145; еаdет, Екстралінгвістична зумовленість термінологіi програмування, баз даних та обробки інформації, „Вісник Харківського університету. Серія: Філологія”, № 491, Харків 2001, s. 272-275; еаdem, Специифіка функиіонування загальновживаної лексики терміносистеми програмування, баз даних та інформаційних технологій, „Вісник Харківського університету. Серія: Філологія”, № 520, Харків 2001, s. $166-170 \mathrm{i}$ in.

15 Л.М. Філюк, Морфологічні способи словотворення термінів інформатики в украйнській мові, „Записки з українського мовознавства: збірник наукових праць”, вип. 14, Одеса 2004, s. 73-80; еаdет, Активність словотвірних способів у творенні украӥнських термінів інформатики, „Записки з українського мовознавства: збірник наукових праць”, вип. 16, Одеса 2006, s. 266-272; еаdет, Шляхи подолання варіантності в украйнській терміносистемі інформатики, „Записки з українського мовознавства: збірник наукових праць”, вип. 18, Одеса 2009, s. $238-249 \mathrm{i}$ in.

16 А. Ліпінська, Проблеми комп'ютерної термінологї̈ української мови, Газета „Університет »Україна«", № 4-5.

${ }^{17}$ І.М. Байбакова, К.В. Байбаков, Англічизми в украӥнських комп'ютерних програмах та мові професіоналів, [w:] Проблеми лінгвістики науково-технічного і художнього тексту та питання лінгвометодики, Львів 2000, s. 61-63.

18 Д.В. Щерба, Засоби запозичення та асиміляція англомовних комп'ютерних термінів, „Вісник Житомирського державного університету імені Івана Франка” 17, Житомир 2004, s. $260-262$.

19 I.I. Григорович, Особливості творення комп'ютерної термінології операційних систем та програмного забезпечення в англійській та украӥнській мовах, „Збірник наукових праць Львівського національного університету імені Івана Франка »Сучасні проблеми лінгвістичних досліджень і методика викладання іноземних мов професійного спілкування у вищій школі«", частина 1, Львів 2007, s. 249-250.

${ }^{20}$ I. Скорейко-Свірська, Граматичне освоєння науково-технічних термінів-іменників англомовного походження в украӥнській мові, „Лінгвістичні студії”, вип. 19, Донецьк 2009, s. $43-49$.

21 А. Костенко, В. Костирко, І. Кульчицький, М. Плеша, Проблеми функціонування украӥнської мови в комп'ютерних технологіях, „Українська термінологія і сучасність: Зб. наук. пр.”, вип. 4, Київ 2001, s. 180-182.

22 P. Jóźwikiewicz, Особливості функиіонування повідомлень у розділі „Високі технологіï” на веб-форумі „Домівка.Net”, „Лінгвокомп'ютерні дослідження” 7, Донецьк 2014, s. 117-122.

${ }^{23}$ Forum dyskusyjne - forma grup dyskusyjnych przeniesiona w obszar stron www służąca wymianie poglądów na dany temat pomiędzy osobami o podobnych zainteresowaniach czy 
oraz blogach ${ }^{24}$, natomiast ich zakres tematyczny ograniczono do problematyki informatycznej. Głównym celem tekstu jest prezentacja konstrukcji najbardziej charakterystycznych dla analizowanych typów komunikacji internetowej, zwłaszcza takich, które podkreślają osobiste zaangażowanie użytkowników w omawiane kwestie. Za materiał badawczy posłużyły teksty składające się na dział informatyczny forum internetowego Domivka.Net ${ }^{25}$ oraz kilka blogów o tematyce informatycznej i okołoinformatycznej ${ }^{26}$.

Przystępując do analizy wypowiedzi funkcjonujących w obu badanych obszarach, należy pamiętać, iż porozumiewanie się via Internet cechują liczne parametry, które w istotny sposób wyróżniają je spośród innych typów komunikacji, znacząco wpływając przy tym na rodzaj stosowanych struktur składniowych.

Najbardziej charakterystycznymi cechami języka komunikacji sieciowej w odniesieniu do forów dyskusyjnych, w nieco mniejszym stopniu zaś do blogów, jest dialogowość, spontaniczność, skrótowość, jak również sytuacyjność oraz dynamiczność. Cechy te, realizujące się w konkretnych wypowiedziach, w szczególny sposób znajdują odzwierciedlenie na poziomie strukturalnym i ,wizualnym" analizowanych materiałów.

Przyglądając się, choćby pobieżnie, poszczególnym postom (należy przy tym pamiętać, że ich autorami są zarówno informatycy, osoby zawodowo lub amatorsko zajmujące się zagadnieniami z dziedziny IT, jak i użytkownicy, którzy niekoniecznie orientują się w kwestiach najnowszych technologii, a ich obecność na forum podyktowana jest koniecznością rozwiązania jakiegoś problemu ze sprzętem, oprogramowaniem itp.), językoznawca zwróci zapewne uwagę na ich profil zdaniowy. Aż nazbyt widoczne jest stosowanie konstrukcji jak najmniej skomplikowanych z punktu widzenia używanych środków. W praktyce przejawia się to $\mathrm{w}$ prostocie zastosowanego słownictwa czy powszechnym występowaniu zdań pojedynczych, co nie oznacza, iż są one konstrukcjami dominującymi. Co ciekawe, znaczny ich procent cechuje swoiście zaznaczona tendencja do egotyzmu, manifestowana głównie przez nagminne użycie zaimka osobowego я (choć równie dobrze mogłyby tu funkcjonować zdania jednoczłonowe, bez wyrażonego podmiotu w postaci zaimka osobowego), np.

\footnotetext{
z podobnymi problemami. Podział forów dyskusyjnych opiera się na wielu kryteriach, np. ich strukturze (płaskie, ustrukturalizowane) czy stopniu anonimowości użytkowników (anonimowe, półanonimowe, restrykcyjne, prywatne).

${ }^{24}$ Blog - typ dziennika, pamiętnika sieciowego, zawiera uporządkowane chronologiczne wpisy jego użytkownika (blogera). Najczęstszym typem bloga uwzględniającym kryterium stosowanych środków wyrazu jest blog tekstowy, choć inne (np. fotoblogi, wideoblogi) nie należą już do rzadkości. Tematyka blogów jest bardzo zróżnicowana: od blogów stricte literackich, po blogi poświęcone modzie, motoryzacji czy informatyce.

25 http://domivka.net/forum.php\#vysoki_tekhnolohii [dostęp: 8.05.2014].

${ }^{26}$ Ubuntu-блог, http://korkholeh.blogspot.com/ [dostęp: 8.05.2014]; Tivasyk@home, http:// www.tivasyk.info/2011/12/blog-post_8535.html\#more [dostęp: 8.05.2014]; Ukrainian IT Blog, http://itblog.org.ua/post/165\#more-165 [dostęp: 8.05.2014].
} 
(1) Я поки нічого із СП ставити не збираюся ${ }^{27}$.

(2) Отож я і протестую.

(3) Я користуюся як основним компом фірмовим сабноутом.

(4) Я останнім часом юзаю Small CD-Writer.

(5) Я тобі на пошту вишлю :)

(6) Я пробував файли закидати на файлшаре.

(7) Я вбив на встановлення два дні. ::(

(8) Я тут програму одну написав під windows.

(9) Я завантажив офіційний українізатор Adobe Photoshop CS3 із сайту www.ukrlocal.info.

jak i użycie samych czasowników w pierwszej osobie lp. w zdaniach jednoczłonowych:

(10) Однак маю проблему с гуглем.

(11) Ось цим ділю диски.

(12) Рекомендую Смулю.

(13) А от рідер українізую залюбки...

(14) Про ігри взагалі мовчу.

(15) Зараз же почну завантажувати!

(16) Встановив 10 екстендед рус. фотошоп.

(17) Через Віндовс апдейт встановив українську мову.

(18) Бачив скріншоти на сайті мікроцифалів.

Te same środki stosowane są naturalnie w obrębie zdań złożonych stanowiących znaczną część analizowanego materiału. Cechą niewątpliwie je wyróżniającą spośród analogicznych struktur, jednak funkcjonujących w obrębie innych jednostek tekstowych, jest notoryczne ignorowanie interpunkcji, stanowiącej przecież integralny element tego rodzaju konstrukcji. Można powiedzieć, iż zjawisko to jest wyróżnikiem komunikacji esemesowej, komunikacji internetowej, zwłaszcza jej odmiany konwersacyjnej, ale również forów internetowych.

Wydaje się, iż wśród zdań polipredykatywnych z wyraźnie zaznaczoną „pierwszoosobowością," współtworzących badane forum, do najczęściej występujących należały struktury hipotaktyczne, w tym przede wszystkim zdania dopełnieniowe, $\mathrm{np}$.

(19) Нагадую, що починаючи з версії 8.1.0 Acrobat вбудовується в Microsoft Office 2007.

(20) Вважаю, що ознайомлення з Language Style Guide може покласти край безплідним балачкам про „правильність перекладу” того чи іншого слова.

(21) Глянув, що це та сама віста тільки з цифрою 7 і зніс нафіг.

(22) Не знав, що на домівці є блоги...

(23) Ще додам, що цей MUI точно підходить лише до російської і англійської версій Windows XP.

${ }^{27}$ Pisownia tego i kolejnych przykładów jest oryginalna. 
Konstrukcje składniowe z utożsamioną osobą piszącego, czy to poprzez obecność formy eksplicytnej zaimka я, czy odpowiednie formy czasownikowe, stanowią znaczną część wyekscerpowanych wypowiedzi, których wyznacznikiem jest prostota, jednoznaczność, lakoniczność. Wśród pozostałych typów zdań złożonych podrzędnie dominują głównie zdania okolicznikowe (przede wszystkim warunkowe i celowe), np.

(24) Якщо не має української проги я спочатку юзаю російську.

(25) Якщо мені хто нагадає за два тижні, то спробую викласти всі українізатори Вінди на якійсь окремій сторінці.

(26) Коли хочу зберегти якийсь малюнок з інету, зависає Опера.

(27) Богдане, дай мені трохи місця на ФТП, щоб я міг закинути цей залатаний українізатор на Домівку.

(28) Можливо хтось зможе розмістити десь на нормальному сайті щоб я міг скачати або по емайл попробуйте закинути БУДЬЛАСКА.

(29) Я зразу побіг в програм файлс, щоб глянути, чи в мене українізована FlashGet - виявилася англійською:(

(30) Я мала перевстановлювати вінду, щоб інсталювати фотошоп поновій.

(31) Я пробував робити так, щоб були тільки ті файли, про які ти казав, але таким чином мені не вдалось його поставити.

(32) Рекомендую наразі залишатись на XР, хоча б до моменту поступлення в продаж 7.

Występowanie struktur złożonych podrzędnie nie wyklucza stosowania konstrukcji współrzędnie złożonych, np.

(33) Тим паче нині наше офіційне сховище мандрує на інший сервер і викласти там зможу лиш за кілька днів.

(34) Записав ВІНДУ на диск, а вона з Bios не запускаєтся.

(35) Я пробував встановити український MUI на WinVI Home Premium, але результат той самий - абсолютно не реагує на запуск файлу...

(36) Для цієї програми я зареєструвався як перекладач, але зараз зовсім немає часу.

(37) Нині вирішив ще перекласти COMODO Cleaning Essentials (портативний антивірус, для перевірки за запитом), але раптом ще щось цікавить шановну спільноту?

To kreowanie siebie w poszczególnych wypowiedziach, tak często uwidaczniające się $w$ postach internetowych, przybiera jeszcze jedną dość zauważalną formę. Struktury z zaimkiem osobowym я, uzupełniane są mianowicie poprzez konstrukcje posesywne typu у мене (є), jak również zdania, w których wspomniany zaimek funkcjonuje w celowniku. Obie formy obecne są zarówno wśród zdań pojedynczych, jak i złożonych, np.

(38) В мене теж вінда злетіла :(

(39) Народ мені треба Укр. Вісту х64. 
(40) А мені можна якось отримати той офіс?

(41) Так для чого ж конкретного мені та віста?

(42) У мене наступна проблема: поставив українську вісту, крекнув і все нормально працювало.

(43) В мене на ХР квадратик (у Вісті показує знак), і як я не старався кодові сторінки, шрифти, розкладки, кодування, ВСЕ-ВСЕ міняв на нове з Вісти всерівно ХР не показує.

Należy jednak pamiętać, że forum internetowe to przede wszystkim platforma, dzięki której możliwa jest wymiana myśli, poglądów, ale też, a może przede wszystkim, udzielanie sobie pomocy w różnych kwestiach. $Z$ tego też względu wypowiedzi forumowiczów dość wyraźnie dadzą się umiejscowić w dwóch kategoriach: pytań i odpowiedzi na nie. W pierwszej kategorii dominują zdania pytające, będące podstawowym elementem niemal każdego wątku, stanowiące fundament jego funkcjonowania, a także po wielokroć pojawiające się w prowadzonych już konwersacjach, np.

(44) То це тільки інтерфейс змінюється, чи взагалі змінюється ОС на $7 \kappa$ ?

(45) Цікаво яка операційна система на сьогоднішній час $є$ най оптимальнішою?

(46) Часом немає інструкції користування українською для Radialix?

(47) А який файл качати і встановлювати: NoCD чи NoCD патч?

(48) GIMP як альтернативу Photoshop'y не пробували?

(49) А скажіть будь ласка Adobe Illustrator i CorelDRAW дуже функціонально відрізняються?

(50) А чому Старт і чому Стільниця якщо Пуск і Робочий стіл??

(51) Чи правильним є переклад англійського „Start” на російське „Пуск” в українському перекладі Windows?

Jednakże forum internetowe to nie tylko przestrzeń służąca manifestowaniu swojego ,ja”, kreowaniu siebie, zadawaniu pytań czy mówieniu o swoich potrzebach, to również miejsce, gdzie zagubiony użytkownik odnajdzie rozwiązanie problematycznych kwestii.

Komunikaty, których celem jest udzielenie odpowiedzi na pytania postawione przez użytkownika danego forum, z punktu widzenia składni realizują się w konstrukcjach, w których centrum predykacji wyrażane jest głównie w trójnasób.

Dość regularnie pojawiają się tu zdania z orzeczeniem w postaci czasownika w 1 os. $1 \mathrm{~m} ., \mathrm{np}$.

(52) 1. Качаємо файл ліцензії NOD32.

2. Вставляємо його в NOD32 (F5 $\rightarrow$ Різне $\rightarrow$ Ліцензії $\rightarrow$ Додати).

3. Створюємо будь-яку папку на диску (наприклад: NOD_UPD).

4. У NOD32 створюємо Дзеркало. F5 $\rightarrow$ Оновлення $\rightarrow$ Додаткові настройки оновлення (настройка) $\rightarrow$ Дзеркало $\rightarrow$ Ставимо галочку Створити дзеркало $\rightarrow$ Вказуємо шлях до створеної вами папці $\rightarrow$ Застосувати. 
5. Оновлення NOD32 (Оновлення $\rightarrow$ Оновити базу даних сигнатур вірусів).

6. Заходимо в вашу створену папку. Там з'явилися бази для оновлення і при кожному оновленні нода, будуть оновлюватися та бази дзеркала.

7. Скідуем папку з базами на флешку і йдемо на інший комп'ютер.

8. На комп'ютері, який хочемо оновити, в настройках оновлення в якості сервера оновлення пропісуем шлях до папки на флешці (F5 $\rightarrow$ Оновлення $\rightarrow$ Сервер оновлень (змінити) $\rightarrow$ Пишемо шлях до папки, тиснемо Додати i Ok.

9. Як сервер оновлень вибераем прописаний вами шлях до папки. Ім'я та пароль залишаємо пустими.

10. Все. Тиснемо оновити.

Taki sposób konstruowania wypowiedzi, odznaczający się swego rodzaju familiarnością, ma za zadanie między innymi stworzenie pewnej ,więzi” między rozmówcami, wywołanie wrażenia nieomylności i niezawodności proponowanych rozwiązań, stanowi również formę kulturalnego pouczenia pytającego, co, jak się okazuje, nie jest dziś zbyt częste w sieci.

Zazwyczaj w tego rodzaju sytuacjach można się natknąć na formy trybu rozkazującego, np.

(53) Перевірте чи точно скрипт на сторінці і скрипт у файлі тотожні однакові.

(54) Почитай те (http://promolab.org/index.php?showtopic=920) i ce (http:// 380971958410.org.ua/platforma-dlya-bloga-obiraemo-optimalnu/).

(55) Краще дай посилання!

(56) Скачайте прогу на кшталт driverscan i вам все буде.

(57) Люди киньте посил на СІМКУ-УКРАЇНСЬКУ, буду вдячний.

(58) Потім видаліть всі макроси, з папки Модулі пустою, збережіть зміни, і подивіться, як буде тоді.

(59) Зайди в налаштування IE та очисти ВЕСЬ кеш.

(60) Перевір комп одноденною утиліткою DWeb на вірус!

(61) 1. Перевір планки пам'яті.

2. Достатня наявність вільного місця на диску C:I

3. Прожени диски на віруси.

4. Перевір диск $\mathrm{C}: \backslash$ на помилки.

5. Для Internet Explorer встанови останню версію JAVA.

6. Прибери з модему лишні речі (можливо літом перегрівається).

7. Пропилисось комп'ютер і кімнату заодно.

8. Постав кондиціонер на кухні.

9. Комп’ютер із кухні перенеси у кімнату.

10. Купи новий компютер $=$ )

Powyższe przykłady są nie tylko ilustracją rysującej się dość specyficznej relacji „mistrz-uczeń”, lecz także do pewnego stopnia nawet lekceważącego czy wręcz prześmiewczego stosunku względem osoby mniej zorientowanej w zagadnieniach informatycznych. 
Mniej protekcjonalne i w swym wydźwięku podobne do pierwszego rodzaju postów są wypowiedzi, w których orzeczenie przybiera formę czasownika w 2 os. lm., np.

(62) Тобто один раз встановлюєте Windows з тими программами які не „Tryout” коли підходить час пересталяєте систему і користуєтеся далі. Windows відновлюється за 3-4 хвилини... далі вдруге встановлюєте програми які мають певний термін дії.

(63) 1. В розділі Regional and Language Options $\rightarrow$ Keyboards and Languages $\rightarrow$ натискаєте Install or uninstall display languages.

2. З'явиться вікно, в ньому натискаєте Install Languages і зазначаєте шлях до папки 3 lp.cab (lp.cab при цьому відображуватись не буде, вказати треба тільки папку).

(64) 1. Встановлюєте ФайнРідер.

2. Встановлюєте цукерку.

3. Користуєтеся на здоров'я, радуєтеся і т. п. і т. д.

Wszystkie przedstawione wyżej typu komunikatów opierają się na niemal bezpośredniej relacji pomiędzy użytkownikami, uczestnikami konwersacji. Do nieco innej kategorii wypowiedzi zamieszczanych w wirtualnym świecie zaliczyć należy wpisy na blogach.

W przeważającej części blogów istnieje możliwość komentowania poszczególnych wpisów, a więc niejako uczestniczenia w dialogu z autorem bloga, jednak nie jest to wymóg. Blog jest gatunkiem w swej istocie opartym na zasadach obowiązujących przy pisaniu pamiętnika czy dziennika, ma zatem cechy bardziej zbliżające go do twórczości literackiej niźli prostych komunikatów wymienianych pomiędzy internautami. Tym specyficznym rodzajem literatury parają się także osoby zajmujące się kwestiami informatycznymi, jednak blog jako środek porozumiewania się nie jest wśród nich szczególnie popularny. Preferowane są szybsze kanały komunikacyjne, niemniej i w ukraińskiej przestrzeni wirtualnej można się natknąć na blogi, których tematem przewodnim (bądź jednym z wątków) są zagadnienia związane z technologiami informacyjnymi.

Pomimo zróżnicowanego poziomu „literackości”, niejako obligatoryjnej obecności słownictwa informatycznego (a także jednostek socjolektu będących wykładnikiem zaawansowania autora i jego wiedzy w tej dziedzinie), określonego wieku, wykształcenia i z reguły wysokiego poziomu kultury osobistej (autorami blogów o tematyce informatycznej są głównie informatycy, studenci związani z IT, hobbyści), wpisy na blogach informatycznych z punktu widzenia składni charakteryzują się między innymi dominacją zdań złożonych (choć trafiają się notatki przesycone lakonicznością, jednak jest to raczej kwestia indywidualnego stylu autora niż ogólna tendencja) oraz wyraźnym wyeksponowaniem konstrukcji pierwszoosobowych ( $1 \mathrm{os}$. lp i lm), natomiast treść samych wypowiedzi cechuje głęboki subiektywizm, informacyjność, niekiedy, co znamienne dla tego typu blogów, nadmierna instruktażowość, np. 
(65) Чи ${ }^{28}$ доводилось вам завантажувати музичні альбоми у вигляді одного APE файлу і CUE файлом з ним на додачу? От і в мене така ситуація іноді трапляється і доводиться проводити конвертацію у формат FLAC з одночасною розбивкою на композиції. Далі - коротка інструкція. Спочатку потрібно встановити декілька пакетів щоб отримати можливість розрізати файли

sudo apt-get install cuetools shntool

Далі, для підтримки формату АРЕ подтрібно завантажити і встановити наступний пакет: mac-3.99-u4 b3-1_i386.deb

Для підтримки FLAC встановлюємо ще декілька пакетів:

sudo apt-get install flac wavpack

Готово. Тепер просто переходимо у каталог з нашим АРЕ файлом і даємо команду:

cuebreakpoints *.cue $\mid$ shnsplit -o flac *.ape;

В результаті в каталозі з'являться FLAC файли, по одному на кожну композицію. Тепер залишається лише прописати теги з допомогою наступної команди:

cuetag *.cue split-track*.flac;

Ось так все просто. Ну, майже.

(66) я ${ }^{29}$ щойно усвідомив одну жахливу річ: google вбив операційні системи, принаймні на користувацьких десктопах і ноутбуках, - i, в принципі, на усих цих windows'ax, linux'ax та macos'ax можна поставити жирного хрестика. ну, тобто «вбив» не дослівно, а фігурально: $з$ точки зору пересічного користувача пк, операційна система втратила значимість (ну гаразд, втратить найближчим часом).

усвідомлення прийшло, коли я зрозумів, що близько двох третин часу роботи з ноутбуком вдома проводжу онлайн, дві третини задач можу виконувати онлайновими інструментами, і дві третини важливих документів (або принаймні копії) вже зберігаю «в хмарі».

тут був величезний допис із спробою розжувати твердження, виділене вгорі. але вольовим зусиллям я змусив себе скоротити допис: все очевидно.

p.s. якщо екстраполювати тенденцію далі - взагалі концепція пк в традиційному розумінні (десктоп, чи навіть ноутбук) потроху втрачає актуальність в цілому сегменті ринку. але про це - в іншому дописі.

(67) Сьогодні ${ }^{30}$, шановний читачу, ми продовжимо розмову про те, як можна автоматизувати процес розробки програмного забезпечення, зменшити витрати часу на допоміжні роботи в великому колективі і сконцентруватись на власне розробці.

\footnotetext{
28 http://www.tivasyk.info/2011/12/blog-post_8535.html\#more [dostęp: 9.05.2014].

${ }^{29} \mathrm{http} / / /$ itblog.org.ua/post/165\#more-165 [dostęp: 8.05.2014].

${ }^{30}$ Ibidem.
} 
У колективі, кожен член якого працює над окремою незалежною частиною, стадія інтеграції $є$ заключною. Саме в ній виявляються проблеми сумісності всіх компонентів системи, через це кінцева дата випуску може бути відсунута на невизначений термін. Саме на зменшення часових та трудових витрат на процес інтеграції за рахунок раннього виявлення проблем та усунення помилок та протиріч спрямовані системи неперервної інтеграції.

Серед таких систем найбільш популярними рішеннями 3 відкритим кодом $є$ CruiseControl та Buildbot. Перший має значно розвиненішу структуру, в той час як другий є легким та простим у налаштуванні. Для початку ж проведемо невеличкий огляд можливостей, переваг та недоліків. Порівняння буде дещо незвичним: воно вестиметься в режимі „перехресного вогню": кожна зі сторін аргументує власні переваги над конкурентом. Це $€$ найкращий варіант для порівняння досить різних за будовою і реалізацією систем, оскільки в більшості випадків характеристики систем між собою не перетинаються. Після такого собі бліц-опитування ми підведемо підсумки у вигляді списку, для більшої наочності.

Każdy z przytoczonych fragmentów na swój sposób wpisuje się w klasyczny obraz wypowiedzi blogowej. Świadczy o tym wiele cech niejako „zewnętrznych” poszczególnych tekstów, tzn. ich tematyczność (w tym przypadku — problematyka informatyczna), zachowanie chronologii poszczególnych postów (wystarczy prześledzić daty), osobisty charakter autorów przejawiający się w „,pierwszoosobowości” wpisów czy ich „literackość”. Charakterystyczne są i inne elementy, między innymi specyficzna grafia, refleksyjność, „wykładowość”, swoisty styl każdego wpisu czy wreszcie dominacja zdań złożonych, a także obecność słownictwa informatycznego oraz jednostek slangu, jak również charakterystycznych zapisów (głównie w języku angielskim) czy dość wyszukanych zwrotów (якщо екстраполювати тенденцію далі itp.) świadczących o wiedzy i elokwencji autorów.

Struktura omawianych sposobów komunikacji w sieci, których bazę leksykalną stanowi ukraińskie słownictwo informatyczne, jest dość zróżnicowana. W dużej mierze uzależniona jest ona od rodzaju samego tekstu, jego ukierunkowania oraz typu odbiorcy. Wybór tych dwóch na pewnym poziomie zbliżonych, a jednak dość odległych pod różnymi względami, rodzajów komunikowania się w sieci miał na celu zaprezentowanie środków, dzięki którym ujawnia się specyfika tych rodzajów przede wszystkim w zakresie składni.

Przytoczone wyżej przykłady wyraźnie wskazują, że posty na forach internetowych poświęconych informatyce charakteryzuje obecność struktur, takich jak np.: zdania rozkazujące, dopełnieniowe, celowe czy warunkowe, występowanie czasowników w formie 1 os. oraz towarzyszącego im zaimka osobowego я. Wpisy na blogach to nieco inny zakres wykorzystywanych środków: począwszy od określonego stylu, poprzez instruktażowość wykładu czy użycie wyszukanego słownictwa, na przemyślanej kompozycji wpisów kończąc. Cechami pozwalającymi umieścić oba rodzaje tekstów we wspólnym zbiorze jest między 
innymi używanie podobnej gamy konstrukcji polipredykatywnych, powszechne zastosowanie terminologii informatycznej, elementów socjolektu informatycznego, specyficznych dla tej dziedziny nauki zapisów (np. komend) czy analogiczne eksponowanie ,ja” autorskiego.

\section{The forums and blogs about computers and IT in the light of selected aspects of Ukrainian language syntax. „I” and internet communication}

\section{Summary}

The forums and blogs about computers and IT are quite a rare phenomenon on the Ukrainian internet. In the article, the author carries out an analysis of these forums and blogs in terms of syntax, with particular attention paid to the constructions in which the person of the author of particular posts becomes visible. The author demonstrates which structures are most frequently employed in such posts and what their character is.

Keywords: The forums and blogs about computers and IT, internet communication, Ukrainian language syntax.

\section{Інтернет-форуми та комп'ютерні блоги у світлі вибраних проблем синтаксису української мови. „Я” та Інтернет-спілкування}

\section{Резюме}

Інтернет-форуми та комп’ютерні блоги — це в україномовному Інтернет-просторі відносно рідке явище. У статті проаналізовано ці структури із синтаксичної точки зору, враховуючи конструкції, в яких проявляються автори окремих дописів. Доведено, котрі структури з'являються в постах найчастіше та якого вони характеру.

Ключові слова: Інтернет-форум, блог, Інтернет-спілкування, синтаксис української мови. 